Article

\title{
Heterogeneous Catalytic Synthesis of 2-Methylbenzimidazole from 2-Nitroaniline and Ethanol Over Mg Modified Cu-Pd $/ \gamma-\mathrm{Al}_{2} \mathrm{O}_{3}$
}

\author{
Feng Feng, Yaqin Deng, Zheng Cheng, Xiaoliang Xu, Qunfeng Zhang *, Chunshan Lu, Lei Ma \\ and Xiaonian $\mathrm{Li}$ * \\ Industrial Catalysis Institute, Laboratory Breeding Base of Green Chemistry-Synthesis Technology, Zhejiang \\ University of Technology, Hangzhou 310014, China; ffeng@zjut.edu.cn (F.F.); dyq8643@gmail.com (Y.D.); \\ chengzheng_83@sina.com (Z.C.); xuxiaoliang@zjut.edu.cn (X.X.); lcszjcn@zjut.edu.cn (C.L.); \\ malei@zjut.edu.cn (L.M.) \\ * Correspondence: zhangqf@zjut.edu.cn (Q.Z.); xnli@zjut.edu.cn (X.L.); Tel.: +86-571-88320920 (Q.Z.); \\ $+86-571-88320002$ (X.L.)
}

Received: 3 December 2018; Accepted: 20 December 2018; Published: 24 December 2018

\begin{abstract}
The direct synthesis of benzimidazoles from 2-nitroaniline and ethanol over $\mathrm{Cu}-\mathrm{Pd} / \gamma-\mathrm{Al}_{2} \mathrm{O}_{3}$ catalysts has the advantages of requiring easily available starting materials, having high efficiency, and a simple procedure. The modification by $\mathrm{Mg}$ of the $\mathrm{Cu}-\mathrm{Pd} / \gamma-\mathrm{Al}_{2} \mathrm{O}_{3}$ catalyst could improve the catalytic activity significantly. The addition of $\mathrm{Mg}$ to the $\mathrm{Cu}-\mathrm{Pd} / \gamma-\mathrm{Al}_{2} \mathrm{O}_{3}$ catalyst could maintain and promote the formation of $\mathrm{CuPd}$ alloy active sites. Meanwhile, the basicity of the support was enhanced appropriately by $\mathrm{Mg}$, which generated more basic sites $\left(\mathrm{Al}-\mathrm{O}^{\delta-}\right)$ to accelerate the dehydrogenation of alcohol and increased the rate of the whole coupled reaction. The 2-nitroaniline was completely converted over $\mathrm{Cu}-\mathrm{Pd} /(\mathrm{Mg}) \gamma-\mathrm{Al}_{2} \mathrm{O}_{3}$ after reacting for six hours, and the yield of 2-methylbenzimidazole was $98.8 \%$. The results of this work provide a simple method to develop a more efficient catalyst for the "alcohol-dehydrogenation, hydrogen transfer and hydrogenation" coupled reaction system.
\end{abstract}

Keywords: 2-Nitroaniline; benzimidazole; heterogeneous catalysis; magnesium modification; $\mathrm{Cu}-\mathrm{Pd} / \gamma-\mathrm{Al}_{2} \mathrm{O}_{3}$

\section{Introduction}

Benzimidazoles are important organic intermediates which can be used as the key structural units of many drugs such as antibacterials, antimicrobials, antifungals, antituberculars, and anti-inflammatories [1-6]. Thus numerous methods for the synthesis of benzimidazoles from o-phenylenediamine and carbonyl derivatives promoted by inorganic acids and various oxidants have been reported, such as $\mathrm{HCl}$ [7], $\mathrm{PPA}$ [8], $\mathrm{Na}_{2} \mathrm{~S}_{2} \mathrm{O}_{5}$ [9], molecular iodine [10], oxone [11], $\mathrm{SnCl}_{2} \cdot \mathrm{H}_{2} \mathrm{O}$ [12], $\mathrm{In}(\mathrm{OTf})_{3}[13], \mathrm{Yb}(\mathrm{OTf})_{3}$ [14], $\mathrm{BF}_{3} \cdot \mathrm{OEt}_{2}$ [15], $\left(\mathrm{Pd}(\mathrm{dppf}) \mathrm{Cl}_{2}\right.$ [16], etc. Although the above reactions were reported to be efficient, there were still many shortcomings in these methods, such as a high demand for equipment and large amounts of waste water due to the use of inorganic acids, difficulty in the separation and recycling of the homogeneous catalysts, many by-products and so on.

In order to find an environmentally friendly, high efficiency, low cost, high atomic and economic method for the synthesis of benzimidazoles, various heterogeneous catalytic systems such as heteropolyacid catalysts [17], modified zeolite catalysts [18], complex metal oxide catalysts [19,20], supported noble metal catalysts [21-23], Cu-PMO catalysts [24] and photocatalytic systems over $\mathrm{Pt}_{-\mathrm{TiO}_{2}}$ [25] were recently reported. In our recent work, the direct synthesis of benzimidazoles from 2-nitroaniline and alcohol in aqueous media catalyzed by $\mathrm{Cu}-\mathrm{Pd} / \gamma-\mathrm{Al}_{2} \mathrm{O}_{3}$ solid catalyst was 
studied [26]. We reported a successfully coupled multi-step reaction including dehydrogenation (Scheme 1. I), transfer hydrogenation (Scheme 1. II) and molecular nucleophilic cyclization, (Scheme 1. III) over a multifunctional heterogeneous catalyst (Scheme 1). The method used a cheaper and more readily available nitroaniline compound as a raw material for the reaction to achieve a simpler process and a substantial enhancement in the yields of desired products [26]. However, the activity of the catalyst was still low and the reaction took at least $12 \mathrm{~h}$ to ensure $100 \%$ conversion of 2 -nitroaniline. It should be the most important factor to limit the reaction rate and the dehydrogenation of alcohol was difficult to achieve, even at $453 \mathrm{~K}$ over a $\mathrm{Cu}-\mathrm{Pd} / \gamma-\mathrm{Al}_{2} \mathrm{O}_{3}$ catalyst.

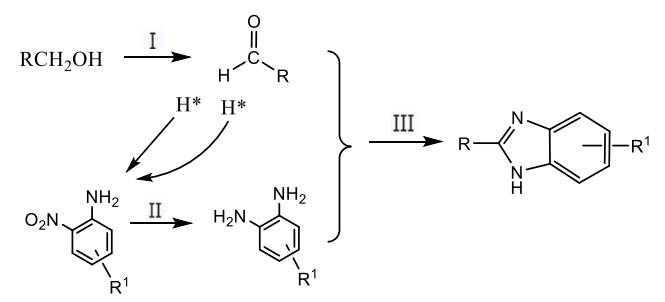

Scheme 1. The mechanism of one-pot synthesis of benzimidazoles from o-nitrophenol and alcohols.

For the supported Ni catalysts, the nature of support has an important role in dehydrogenation of alcohols $[27,28]$, in which the bifunctional support with both acidity-basicity is superior to the single acid or base support. Shimizu et al. [28] proposed that alcohol was converted to an alkoxide group on Lewis acid sites $\left(\mathrm{Al}^{\delta+}\right)$ and a proton on Lewis basic sites $\left(\mathrm{Al}^{-\mathrm{O}^{\delta-}}\right)$ respectively over alumina. Alkoxide was then reacted with $\mathrm{Ni}^{0}$ to form ketone or aldehyde and $\mathrm{Ni}-\mathrm{H}$ hydrides, followed by the protolysis of $\mathrm{Ni}-\mathrm{H}$ hydrides and a neighboring proton to generate $\mathrm{H}_{2}$ and regenerate $\mathrm{Ni}^{0}$ and $\mathrm{Al}-\mathrm{O}^{\delta-}$ sites. Based on the mechanism presented above, it was suggested that the base sites of support were necessary to abstract the proton from alcohol. Thus, the appropriate amount of acid-base sites on the $\gamma-\mathrm{Al}_{2} \mathrm{O}_{3}$ surface is advantageous to accelerate the dehydrogenation of alcohol, which is the rate-determining step of the direct synthesis process of benzimidazoles from 2-nitroaniline and alcohol.

Therefore, we have reasons to believe that the adjusting of the acidity and basicity of the $\mathrm{Cu}-\mathrm{Pd} / \gamma-\mathrm{Al}_{2} \mathrm{O}_{3}$ catalyst surface has an important influence on the rate of this complex reaction. Inspired by previous researchers, $\mathrm{Mg}$ was selected as the secondary additive to add to the $\mathrm{Pd}$-based catalyst in this paper. The effect of an addition of $\mathrm{Mg}$ to the $\mathrm{Cu}-\mathrm{Pd} / \gamma-\mathrm{Al}_{2} \mathrm{O}_{3}$ bimetallic catalyst in the hydrogenation of 2-Nitroaniline was also investigated. The results of this work can contribute to improving performance of catalysts for coupling of "dehydrogenation-hydrogen transfer-hydrogenation" multi-step reactions.

\section{Results and Discussion}

\subsection{Synthesis of Benzimidazoles Over $\mathrm{Pd}-\mathrm{Cu} / \gamma-\mathrm{Al}_{2} \mathrm{O}_{3}$ Based Catalysts}

The reaction of o-nitroaniline with ethanol over the catalysts was performed, and the results are listed in Table 1. 2-Methylbenzimidazole was the main product while 2-propylbenzimidazole was formed as a byproduct. 2-Propylbenzimidazole might be formed through self-aldolization of acetaldehyde to crotonaldehyde [29]. The $\mathrm{Pd} / \gamma-\mathrm{Al}_{2} \mathrm{O}_{3}$ catalyst gave low conversion of o-nitroaniline and a low yield of benzimidazole, whereas the $\mathrm{Cu} / \gamma-\mathrm{Al}_{2} \mathrm{O}_{3}$ catalyst showed no activity (entries 1-2). When blending $\mathrm{Cu} / \gamma-\mathrm{Al}_{2} \mathrm{O}_{3}$ and $\mathrm{Pd} / \gamma-\mathrm{Al}_{2} \mathrm{O}_{3}$ physically as the catalyst, the conversion of o-nitroaniline was only $67.3 \%$, and the yield of 2-methylbenzimidazole was $64.7 \%$ within $12 \mathrm{~h}$ (entry 3). The yield of 2-methylbenzimidazole reached $89.2 \%$ within $6 \mathrm{~h}$ using $\mathrm{Cu}-\mathrm{Pd} / \gamma-\mathrm{Al}_{2} \mathrm{O}_{3}$ as the catalyst (entry 4). From these results, it might be deduced that $\mathrm{Cu}$-Pd bimetallic catalysts could effectively catalyze the formation of benzimidazoles from o-nitroaniline with ethanol. The higher activity of the $\mathrm{Cu}$-Pd catalyst was attributed to the accompanying synergistic interaction between $\mathrm{Pd}$ and $\mathrm{Cu}$ by forming CuPd alloy compound [26]. Surprisingly the addition of alkali metal and alkaline earth metal 
could effectively promote the reaction and enhance the selectivity. Also, the modification by different alkali additives can affect the activity of $\mathrm{Cu}-\mathrm{Pd} / \gamma-\mathrm{Al}_{2} \mathrm{O}_{3}$ catalysts. The conversion of o-nitroaniline was significantly increased by doping $\mathrm{Mg}$, $\mathrm{K}$ and $\mathrm{Sr}$ (entries 5, 7, 10), and the highest benzimidazole yield was obtained over the $\mathrm{Cu}-\mathrm{Pd} /(\mathrm{Mg}) \gamma-\mathrm{Al}_{2} \mathrm{O}_{3}$ catalyst. The effect on the catalytic activity of the $\mathrm{Ca}, \mathrm{Cs}, \mathrm{Ba}$, and La-modified catalysts were relatively weak in comparison with that of the Mg-modified catalyst.

Table 1. Evaluation of the catalytic activity of various catalysts.

\begin{tabular}{|c|c|c|c|c|}
\hline & $\overbrace{\mathrm{NH}_{2}}^{\mathrm{NO}_{2}}+\mathrm{CH}_{3} \mathrm{CH}_{2} \mathrm{OH}$ & $\mathrm{H} \frac{\mathrm{Cu}-\mathrm{Pd} /(\mathrm{M}) \gamma-\mathrm{Al}_{2} \mathrm{O}_{3}}{\mathrm{H}_{2} \mathrm{O}, \mathrm{N}_{2}, 453 \mathrm{~K}}$ & & \\
\hline Entry & Catalyst $^{a}$ & Reaction Time (h) & Conv. (\%) & Yield $(\%)^{b}$ \\
\hline 1 & $\mathrm{Cu} / \gamma-\mathrm{Al}_{2} \mathrm{O}_{3}$ & 12 & 0 & 0 \\
\hline 2 & $\mathrm{Pd} / \gamma-\mathrm{Al}_{2} \mathrm{O}_{3}$ & 12 & 6.5 & 6.5 \\
\hline 3 & $\mathrm{Cu} / \mathrm{Al}_{2} \mathrm{O}_{3}+\mathrm{Pd} / \gamma-\mathrm{Al}_{2} \mathrm{O}_{3}$ & 12 & 67.3 & 64.7 \\
\hline 4 & $\mathrm{Cu}-\mathrm{Pd} / \gamma-\mathrm{Al}_{2} \mathrm{O}_{3}$ & 6 & 89.5 & 89.2 \\
\hline 5 & $\mathrm{Cu}-\mathrm{Pd} /(\mathrm{Mg}) \gamma-\mathrm{Al}_{2} \mathrm{O}_{3}$ & 6 & 100 & 98.8 \\
\hline 6 & $\mathrm{Cu}-\mathrm{Pd} /(\mathrm{Ca}) \gamma-\mathrm{Al}_{2} \mathrm{O}_{3}$ & 6 & 83.5 & 82.9 \\
\hline 7 & $\mathrm{Cu}-\mathrm{Pd} /(\mathrm{Sr}) \gamma-\mathrm{Al}_{2} \mathrm{O}_{3}$ & 6 & 99.1 & 98.2 \\
\hline 8 & $\mathrm{Cu}-\mathrm{Pd} /(\mathrm{Ba}) \gamma-\mathrm{Al}_{2} \mathrm{O}_{3}$ & 6 & 95.7 & 95.0 \\
\hline 9 & $\mathrm{Cu}-\mathrm{Pd} /(\mathrm{Na}) \gamma-\mathrm{Al}_{2} \mathrm{O}_{3}$ & 6 & 95.5 & 96.6 \\
\hline 10 & $\mathrm{Cu}-\mathrm{Pd} /(\mathrm{K}) \gamma-\mathrm{Al}_{2} \mathrm{O}_{3}$ & 6 & 100 & 98.3 \\
\hline 11 & $\mathrm{Cu}-\mathrm{Pd} /(\mathrm{Cs}) \gamma-\mathrm{Al}_{2} \mathrm{O}_{3}$ & 6 & 98.4 & 97.8 \\
\hline 12 & $\mathrm{Cu}-\mathrm{Pd} /(\mathrm{La}) \gamma-\mathrm{Al}_{2} \mathrm{O}_{3}$ & 6 & 96.8 & 94.2 \\
\hline
\end{tabular}

Reaction conditions: Catalyst $0.8 \mathrm{~g}$, o-nitroaniline $8 \mathrm{~g}$, ethanol $120 \mathrm{~mL}, \mathrm{H}_{2} \mathrm{O} 80 \mathrm{~mL}, 453 \mathrm{~K}, \mathrm{~N}_{2} 3.5 \mathrm{MPa}$. (a) $5 \mathrm{w}$ t. $\%$ content for each metal including $\mathrm{Cu}, \mathrm{Pd}$ and (M). (b) Yield of 2-methylbenzimidazole (1) as determined by GC analysis.

\subsection{Effect of Mg Modification on the Formation of CuPd Alloy}

According to reported literature, $\mathrm{Pd}-\mathrm{Cu}$ bimetallic catalysts were used in various reactions to improve the selectivity of target products such as the degradation of nitrates [30] and the steam reforming of methanol [31]. In our previous work [26], the superior catalytic performance of $\mathrm{Cu}-\mathrm{Pd} / \gamma-\mathrm{Al}_{2} \mathrm{O}_{3}$ catalysts was attributed to the formation of the $\mathrm{CuPd}$ compound: The active component $\mathrm{Cu}$ promoted the dehydrogenation of alcohol to aldehyde, and at the same time, $\mathrm{Pd}$ promoted transfer hydrogenation of o-nitroaniline to o-phenylendiamine, the synergistic interaction between $\mathrm{Pd}$ and $\mathrm{Cu}$ makes the reaction proceed smoothly. Therefore, the enhancement of catalytic performance of the Mg-doped catalysts in this work might be related to the stimulative formation of the CuPd alloy.

The HRTEM analysis of $\mathrm{Cu}-\mathrm{Pd} /(\mathrm{Mg}) \gamma-\mathrm{Al}_{2} \mathrm{O}_{3}$ catalysts were performed and the results are shown in Figure 1A,B. Lattice fringe images of monometallic Pd particles show the lattice spacings at $2.27 \AA$, $1.97 \AA$, and $1.40 \AA$ corresponding to (111), (200), (220) planes of Pd. Fourier transforms analysis (FFT) of high resolution images of $\mathrm{Cu}$-Pd bimetallic catalyst particles show the lattice spacings at $2.18 \AA$, $1.89 \AA$, and $1.38 \AA$ corresponding to (111), (200), (220) planes of CuPd, which are lower than the Pd metallic spacing. It could suggest the existence of the $\mathrm{CuPd}$ alloy structure in the bimetallic catalysts. The mean size of metal particles for $\mathrm{Cu}-\mathrm{Pd} /(\mathrm{Mg}) \gamma-\mathrm{Al}_{2} \mathrm{O}_{3}$ is about $7.2 \mathrm{~nm}$ (Figure 1C). These results suggested that the $\mathrm{CuPd}$ alloy was the primary active component in the $\mathrm{Cu}-\mathrm{Pd} /(\mathrm{Mg}) \gamma-\mathrm{Al}_{2} \mathrm{O}_{3}$ catalyst, and that the CuPd alloy was highly dispersed on the surface of the support. 


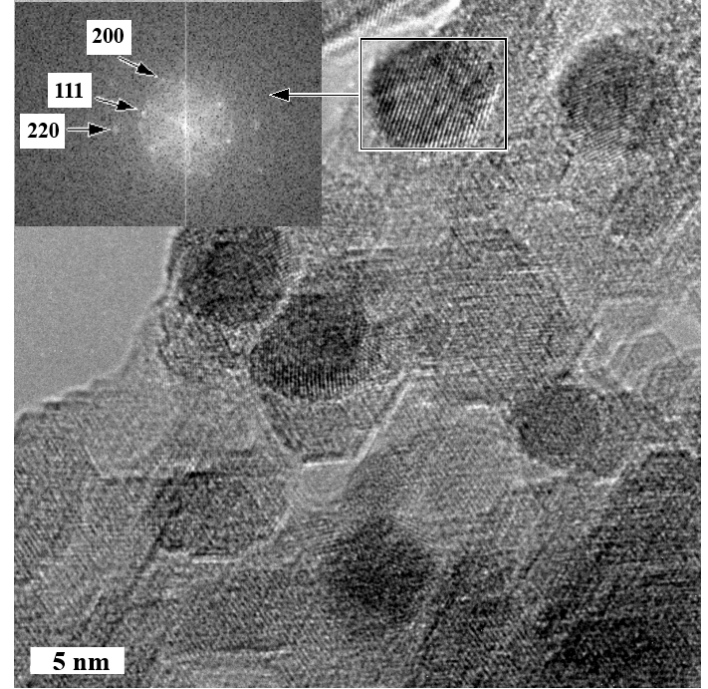

A

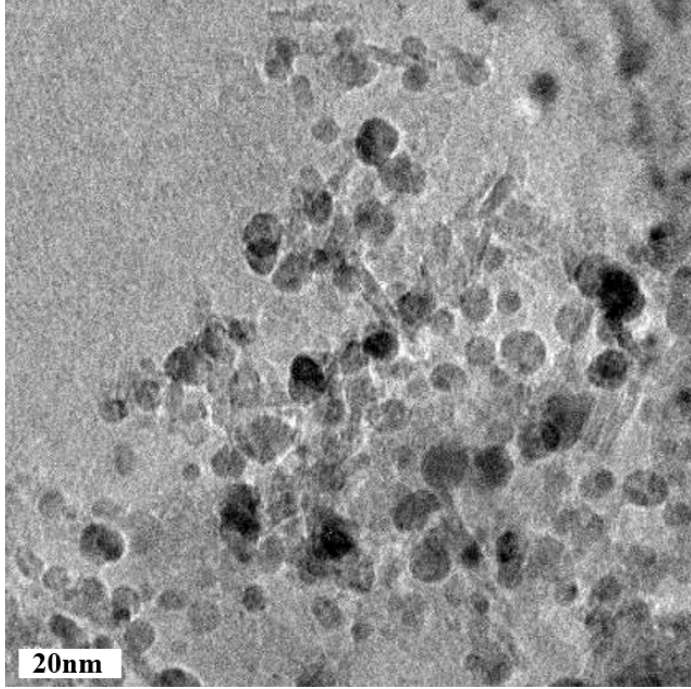

B

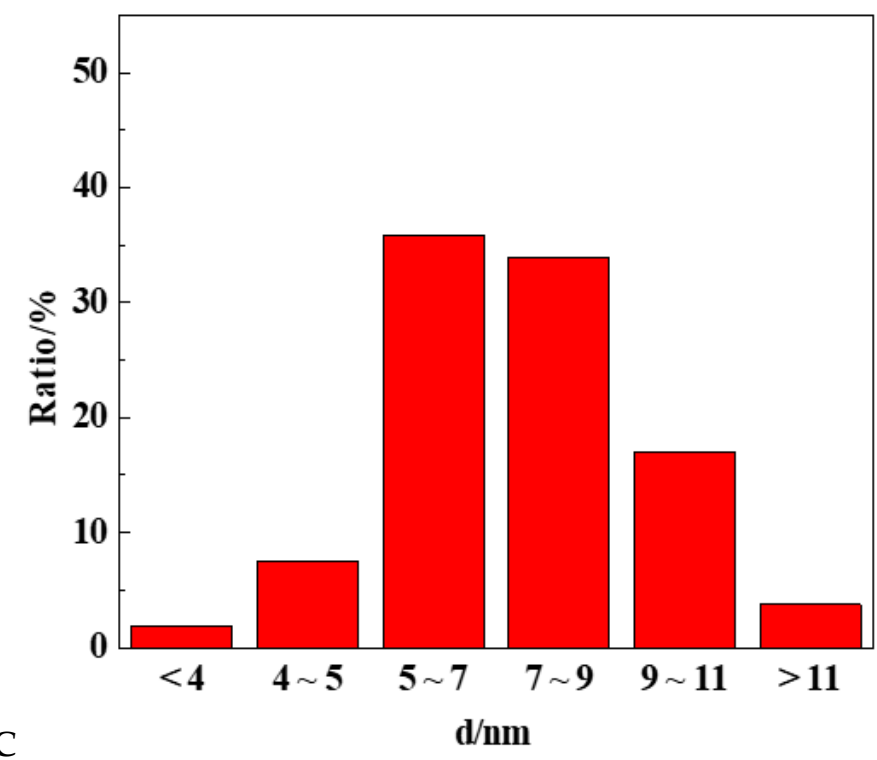

Figure 1. (A,B) TEM images and (C) particle size distribution profiles of $\mathrm{Cu}-\mathrm{Pd} /(\mathrm{Mg}) \gamma-\mathrm{Al}_{2} \mathrm{O}_{3}$ catalysts.

Figure 2 shows the TPR profiles of the calcined samples. The $\mathrm{PdO} / \gamma-\mathrm{Al}_{2} \mathrm{O}_{3}$ sample showed a negative peak at $361 \mathrm{~K}$, corresponding to liberated hydrogen during the decomposition of $\mathrm{Pd}$ hydride [32-34], which indicated that $\mathrm{PdO}$ was already reduced to $\mathrm{Pd}^{0}$ at room temperature. The $\mathrm{CuO} / \gamma-\mathrm{Al}_{2} \mathrm{O}_{3}$ sample displayed a reduction peak with two maxima at $477 \mathrm{~K}$ and $528 \mathrm{~K}$. The reduction peak at low temperature might be attributed to the reduction of superficial $\mathrm{Cu}_{2} \mathrm{O}$ to $\mathrm{Cu}^{0}$ and the reduction peak at high temperature might be assigned to the reduction of $\mathrm{CuO}$ to $\mathrm{Cu}^{0}$ [35]. However, for the $\mathrm{Cu}$-Pd-based samples, the negative peak at $361 \mathrm{~K}$ completely disappeared, and only a hydrogen desorption peak was shown at around $406 \mathrm{~K}$, indicating that the formation of Pd hydride is inhibited with the addition of $\mathrm{Cu}$ [33]. The displacement of reduction peak in the TPR profiles of (c) and (d) also indicate that the $\mathrm{Cu}$ oxides could be reduced at a much lower temperature in the presence of $\mathrm{Pd}$, resulting from the hydrogen spillover from $\mathrm{Pd}^{0}$ to $\mathrm{Cu}$ oxides [34]. Thus, it could be seen that there was an interaction between $\mathrm{Pd}$ and $\mathrm{Cu}$ species in the $\mathrm{Cu}$-Pd-bimetallic catalysts which generated the $\mathrm{CuPd}$ alloy formation. Furthermore, by comparing the TPR profiles of (c) and (d), it indicated that the addition of $\mathrm{Mg}$ had negligible influence on the position of reduction peak, but the reduction peak area of CuPd alloy increased obviously. 


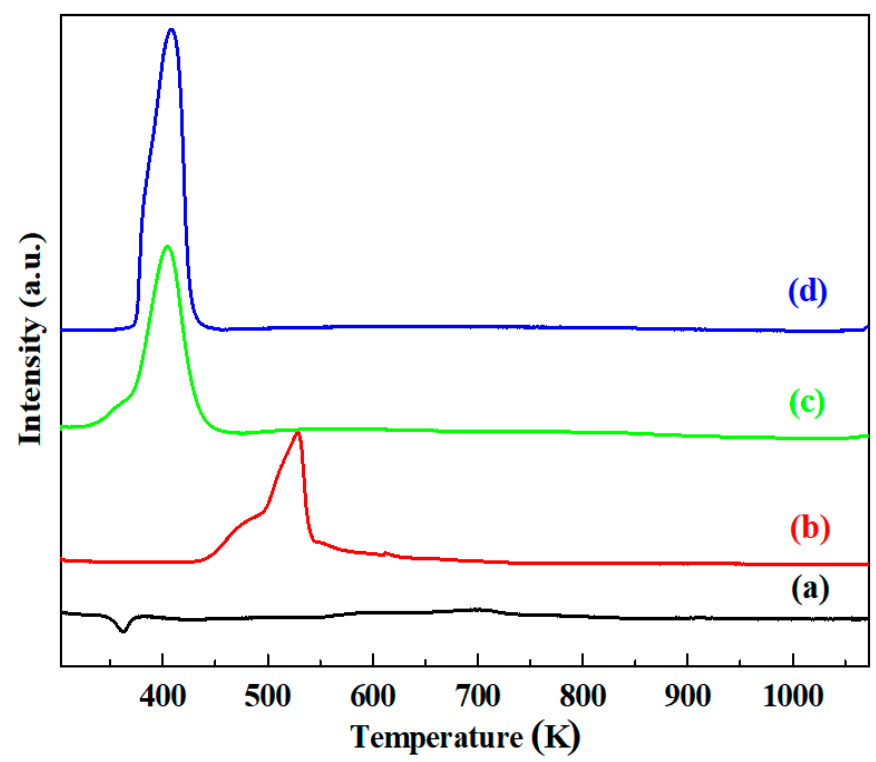

Figure 2. TPR profiles of catalysts: (a) $\mathrm{PdO} / \gamma-\mathrm{Al}_{2} \mathrm{O}_{3} ;$ (b) $\mathrm{CuO} / \gamma-\mathrm{Al}_{2} \mathrm{O}_{3}$; (c) $\mathrm{CuO}-\mathrm{PdO} / \gamma-\mathrm{Al}_{2} \mathrm{O}_{3}$; (d) $\mathrm{CuO}-\mathrm{PdO} /(\mathrm{Mg}) \gamma-\mathrm{Al}_{2} \mathrm{O}_{3}$.

Figure 3 shows the XRD patterns of the reduced catalyst samples. All catalyst samples exhibited diffraction peaks at $2 \theta=66.7^{\circ}, 45.8^{\circ}$ and $37.6^{\circ}$ corresponding to a $\gamma-\mathrm{Al}_{2} \mathrm{O}_{3}$ structure. Diffraction peaks of the $\mathrm{Pd} / \gamma-\mathrm{Al}_{2} \mathrm{O}_{3}$ catalyst and pure $\gamma-\mathrm{Al}_{2} \mathrm{O}_{3}$ carrier were basically identical. The peaks at $43.3^{\circ}, 50.4^{\circ}$ and $74.1^{\circ}$ corresponding to $\mathrm{Cu}$ were observed with the $\mathrm{Cu} / \gamma-\mathrm{Al}_{2} \mathrm{O}_{3}$ catalyst. For the $\mathrm{Cu}-\mathrm{Pd} / \gamma-\mathrm{Al}_{2} \mathrm{O}_{3}$ and $\mathrm{Cu}-\mathrm{Pd} /(\mathrm{Mg}) \gamma-\mathrm{Al}_{2} \mathrm{O}_{3}$ catalysts, no $\mathrm{Cu}$ diffraction peak was found, but the diffraction peaks at $2 \theta=41.6^{\circ}, 48.3^{\circ}$ and $70.8^{\circ}$ which are characteristic of (111), (200) and (220) planes for CuPd alloy respectively [31,36], were observed. The intensity of the CuPd alloy diffraction peaks of $\mathrm{Cu}-\mathrm{Pd} /(\mathrm{Mg}) \gamma-\mathrm{Al}_{2} \mathrm{O}_{3}$ was much higher than that of $\mathrm{Cu}-\mathrm{Pd} / \gamma-\mathrm{Al}_{2} \mathrm{O}_{3}$. Besides, the peak of $\mathrm{MgO}$ phase was not found in the XRD patterns of the $\mathrm{Cu}-\mathrm{Pd} /(\mathrm{Mg}) \gamma-\mathrm{Al}_{2} \mathrm{O}_{3}$ catalyst and the characteristic peaks of $\gamma-\mathrm{Al}_{2} \mathrm{O}_{3}$ had no obvious change. The content of $\mathrm{Mg}$ was low, and $\mathrm{Mg}$ was well dispersed in the $\gamma-\mathrm{Al}_{2} \mathrm{O}_{3}$ rather than assembled in grains. Both of the TPR and XRD results indicated that the addition of $\mathrm{Mg}$ might promote the formation of the CuPd alloy.

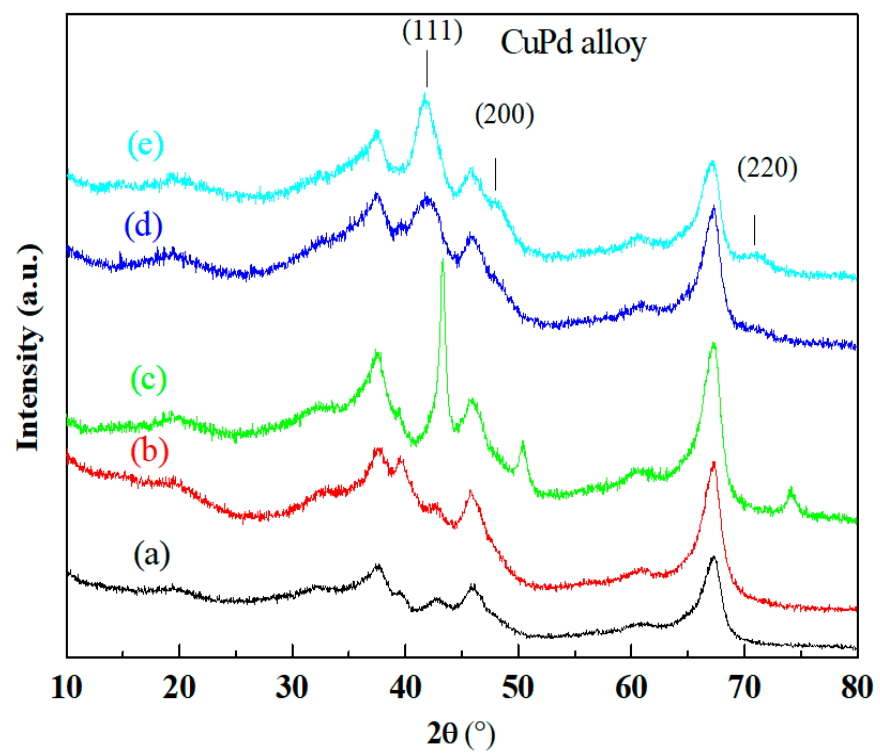

Figure 3. X-ray diffraction patterns of the reduced catalysts (a) $\gamma-\mathrm{Al}_{2} \mathrm{O}_{3}$; (b) $\mathrm{Pd} / \gamma-\mathrm{Al}_{2} \mathrm{O}_{3}$; (c) $\mathrm{Cu} / \gamma-\mathrm{Al}_{2} \mathrm{O}_{3} ;(\mathbf{d}) \mathrm{Cu}-\mathrm{Pd} / \gamma-\mathrm{Al}_{2} \mathrm{O}_{3} ;(\mathbf{e}) \mathrm{Cu}-\mathrm{Pd} /(\mathrm{Mg}) \gamma-\mathrm{Al}_{2} \mathrm{O}_{3}$. 


\subsection{Effect of $\mathrm{Mg}$ Modification on the Surface Acidity and Basicity of Catalysts}

Besides the effect on the formation of CuPd alloy, the modification of $\mathrm{Mg}$ could influence the surface chemical properties of the $\mathrm{Cu}-\mathrm{Pd} / \gamma-\mathrm{Al}_{2} \mathrm{O}_{3}$ catalyst significantly. The $\mathrm{CO}_{2}$-TPD analysis was examined to investigate the effect on the surface basicity of the $\mathrm{Cu}-\mathrm{Pd} / \gamma-\mathrm{Al}_{2} \mathrm{O}_{3}$ catalyst with the addition of $\mathrm{Mg}$, and the results are shown in Figure 4. Both the $\mathrm{Cu}-\mathrm{Pd} / \gamma-\mathrm{Al}_{2} \mathrm{O}_{3}$ and $\mathrm{Cu}-\mathrm{Pd} /(\mathrm{Mg}) \gamma-\mathrm{Al}_{2} \mathrm{O}_{3}$ catalysts showed the desorption peak of $\mathrm{CO}_{2}$ at $385-395 \mathrm{~K}$, which should be attributed to the low basicity sites on catalyst surface formed by Brønsted $\mathrm{OH}$ groups $[37,38]$. Both of two catalyst samples showed a desorption peak over $573 \mathrm{~K}$, which corresponded to the high basicity sites resulting from low coordination oxygen anions $\left(\mathrm{O}^{2-}\right)[37,38]$. However, the concentrations of high and low basicity sites in the $\mathrm{Cu}-\mathrm{Pd} /(\mathrm{Mg}) \gamma-\mathrm{Al}_{2} \mathrm{O}_{3}$ catalyst were higher than that in the $\mathrm{Cu}-\mathrm{Pd} / \gamma-\mathrm{Al}_{2} \mathrm{O}_{3}$ catalyst, and the peak for high basicity sites shifted to a high temperature range in the $\mathrm{Cu}-\mathrm{Pd} /(\mathrm{Mg}) \gamma-\mathrm{Al}_{2} \mathrm{O}_{3}$ catalyst. Moreover, another desorption peak at $430 \mathrm{~K}$ corresponding to medium basicity sites generated from metal-oxygen pairs ( ${\mathrm{M}-\mathrm{O}^{\delta-}}^{\delta}$ pairs) $[37,38]$ was observed in the $\mathrm{Cu}-\mathrm{Pd} /(\mathrm{Mg}) \gamma-\mathrm{Al}_{2} \mathrm{O}_{3}$ catalyst but not found in the $\mathrm{Cu}-\mathrm{Pd} / \gamma-\mathrm{Al}_{2} \mathrm{O}_{3}$ catalyst. These $\mathrm{CO}_{2}-\mathrm{TPD}$ results suggested that the basicity intensity and concentration especially the medium and strong basic sites of the $\mathrm{Cu}-\mathrm{Pd} / \gamma-\mathrm{Al}_{2} \mathrm{O}_{3}$ catalyst could be promoted by the doping of $\mathrm{Mg}$.

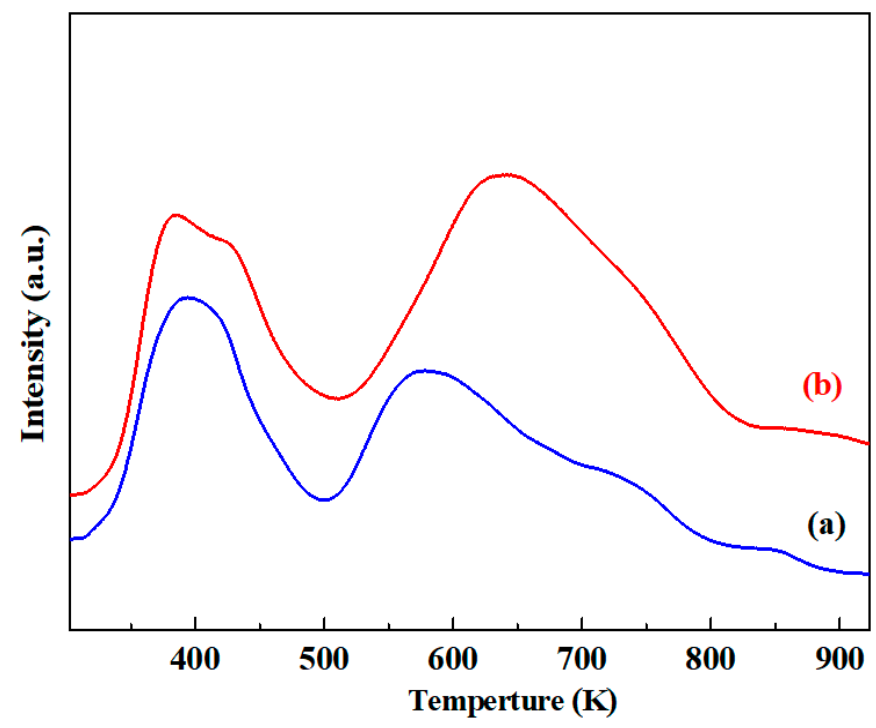

Figure 4. $\mathrm{CO}_{2}$-TPD profiles for catalyst samples: (a) $\mathrm{Cu}-\mathrm{Pd} / \gamma-\mathrm{Al}_{2} \mathrm{O}_{3} ;(\mathbf{b}) \mathrm{Cu}-\mathrm{Pd} /(\mathrm{Mg}) \gamma-\mathrm{Al}_{2} \mathrm{O}_{3}$.

Figure 5 shows the FTIR spectra of adsorbed pyridine (Py-FTIR) at different temperatures for various catalysts. The spectrum of the $\mathrm{Cu}-\mathrm{Pd} / \gamma-\mathrm{Al}_{2} \mathrm{O}_{3}$ catalyst contained three main peaks at 1448 , $1488,1598 \mathrm{~cm}^{-1}$, which are responsible for Lewis acid sites [39], after being evacuated at $303 \mathrm{~K}$. However, the intensity of the three peaks was much higher than that of $\mathrm{Cu}-\mathrm{Pd} /(\mathrm{Mg}) \gamma-\mathrm{Al}_{2} \mathrm{O}_{3}$. The spectrum of the $\mathrm{Cu}-\mathrm{Pd} / \gamma-\mathrm{Al}_{2} \mathrm{O}_{3}$ catalyst after being evacuated at $473 \mathrm{~K}$ contained two peaks at 1449 and $1608 \mathrm{~cm}^{-1}$, which indicated the presence of strong Lewis acid sites. Furthermore, the peak at $1549 \mathrm{~cm}^{-1}$, that is responsible for Brønsted acid sites [40], was detected in the $\mathrm{Cu}-\mathrm{Pd} / \gamma-\mathrm{Al}_{2} \mathrm{O}_{3}$ catalyst but disappeared with the addition of $\mathrm{Mg}$, indicating a deactivation of acid sites through $\mathrm{Mg}$ doping. 


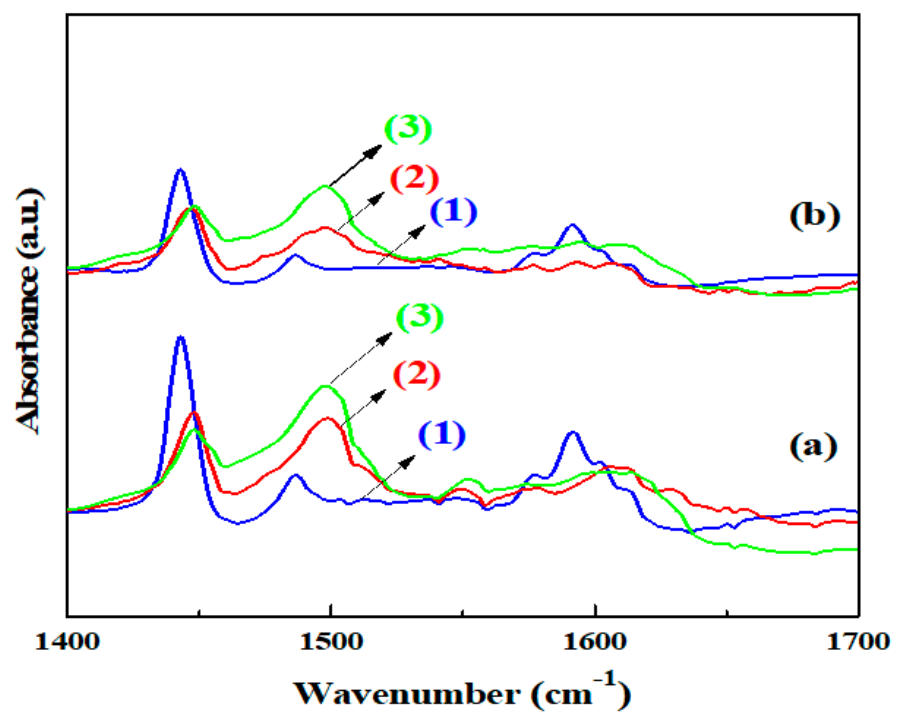

Figure 5. FTIR spectra of pyridine adsorbed of the samples: (a) Cu-Pd/ $\gamma-\mathrm{Al}_{2} \mathrm{O}_{3}$ measured after heating at (1) $303 \mathrm{~K},(2) 373 \mathrm{~K},(3) 473 \mathrm{~K}$; (b) $\mathrm{Cu}-\mathrm{Pd} /(\mathrm{Mg}) \gamma-\mathrm{Al}_{2} \mathrm{O}_{3}$ measured after heating at (1) $303 \mathrm{~K}$, (2) $373 \mathrm{~K}$, (3) $473 \mathrm{~K}$.

The $\mathrm{CO}_{2}$-TPD and Py-FTIR results suggested that the strong Lewis and Brønsted acid sites on the $\mathrm{Cu}-\mathrm{Pd} / \gamma-\mathrm{Al}_{2} \mathrm{O}_{3}$ catalyst surface were reduced by the doping of $\mathrm{Mg}$. Meanwhile, the basic $\mathrm{Al}-\mathrm{O}^{\delta-}$ groups of $\mathrm{Cu}-\mathrm{Pd} /(\mathrm{Mg}) \gamma-\mathrm{Al}_{2} \mathrm{O}_{3}$ catalyst were increased, which made Lewis acid $\left(\mathrm{Al}^{\delta+}\right)$-base $\left(\mathrm{Al}-\mathrm{O}^{\delta-}\right)$ equilibrium of the catalyst. The $\mathrm{Cu}-\mathrm{Pd} /(\mathrm{Mg}) \gamma-\mathrm{Al}_{2} \mathrm{O}_{3}$ catalyst was most likely to follow a multifunctional mechanism in the dehydrogenation of alcohols which was similar to previous reports [28]. Both the $\mathrm{Cu}^{0}$ and the acid-basic sites on the $(\mathrm{Mg}) \gamma-\mathrm{Al}_{2} \mathrm{O}_{3}$ support were responsible for promoting dehydrogenation of alcohol to aldehyde, resulting in the acceleration of the whole reaction system.

Finally, the fascinating applicability of the method towards diversified 4,4'-Diamino-3,3'dinitrobiphenyl and alcohol prompted us to design some more complex benzimidazole derivatives that can serve as lead compounds in pharmaceutical research. To our delight, we were able to synthesize a bisbenzimidazole (3) through a reaction between 4,4'-Diamino-3,3'-dinitrobipheny (1) and alcohol (2) at an excellent yield (Scheme 2). As experimental results showed, 4,4'-Diamino-3,3'-dinitrobiphenyl was almost completely converted to bisbenzimidazole over the $\mathrm{Cu}-\mathrm{Pd} /(\mathrm{Mg}) \gamma-\mathrm{Al}_{2} \mathrm{O}_{3}$ catalyst within $6 \mathrm{~h}$, and bisbenzimidazole was obtained an a $98 \%$ yield.

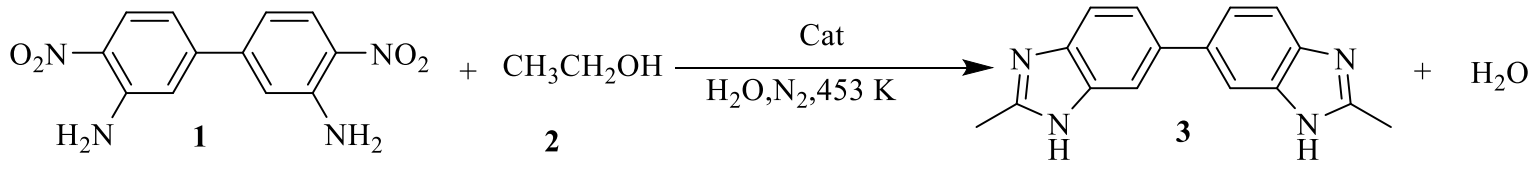

Scheme 2. Synthesis of bisbenzimidazole from 4,4'-diamino-3,3'-dinitrobipheny and alcohol. Reaction conditions: 3,3'-Dinitrobenzidine (2 g), $\mathrm{H}_{2} \mathrm{O}(20 \mathrm{~mL})$, ethanol $(50 \mathrm{~mL})$, Cat $(0.2 \mathrm{~g}), 453 \mathrm{~K}, 3.5 \mathrm{MPa}, \mathrm{N}_{2}$ atmosphere, Yield: $98 \%$ (6 h).

\section{Materials and Methods}

\subsection{Catalyst Preparation}

The $(\mathrm{M}) \gamma-\mathrm{Al}_{2} \mathrm{O}_{3}$ supports $(\mathrm{M}=\mathrm{Na}, \mathrm{K}, \mathrm{Cs}, \mathrm{Mg}, \mathrm{Ca}, \mathrm{Sr}, \mathrm{Ba}, \mathrm{La})$ were prepared by an incipient wetness method. All supports were prepared by the impregnation of $\gamma-\mathrm{Al}_{2} \mathrm{O}_{3}$ with an aqueous solution of alkaline or alkaline earth nitrate ( $5 \mathrm{wt}$. \% content for M). After impregnation, the sample was dried in the oven at $383 \mathrm{~K}$ for $12 \mathrm{~h}$ and then was calcined at $673 \mathrm{~K}$ for $4 \mathrm{~h}$ in air. The Cu-Pd/(M) $\gamma-\mathrm{Al}_{2} \mathrm{O}_{3}$ 
catalysts were prepared by a deposition-precipitation method. Sufficient amounts of $\mathrm{H}_{2} \mathrm{PdCl}_{4}$ and $\mathrm{Cu}$ $\left(\mathrm{NO}_{3}\right)_{2} \cdot 3 \mathrm{H}_{2} \mathrm{O}$ aqueous solutions were mixed together (to produce a catalyst containing $5 \mathrm{wt}$. \% Pd and $5 \mathrm{wt}$. $\% \mathrm{Cu}$ ). This mixture was added dropwise to a $10 \mathrm{wt}$. \% slurry of $\gamma-\mathrm{Al}_{2} \mathrm{O}_{3}$ (or $(\mathrm{M}) \gamma-\mathrm{Al}_{2} \mathrm{O}_{3}$ ) and deionized water, with constant stirring by a magnetic stirring apparatus. The temperature was increased to $353 \mathrm{~K}$ and kept at this temperature for $5 \mathrm{~h}$. After impregnation, the $\mathrm{NaHCO}_{3}$ solution $(1 \mathrm{M})$ was used to adjust the $\mathrm{pH}$ value of the solution to 8-9, and stirring continued for $30 \mathrm{~min}$. Then, the solid was filtered, washed, dried at $383 \mathrm{~K}$ for $4 \mathrm{~h}$ and calcined in air at $533 \mathrm{~K}$ for $4 \mathrm{~h}$. Finally, the samples were reduced in $\mathrm{H}_{2}$ at $533 \mathrm{~K}$ for $2 \mathrm{~h}$.

\subsection{Catalyst Characterization}

The X-ray diffraction (XRD) of catalysts was carried out with an $X^{\prime}$ Pert PRO diffractometer (PNAlytical Co., Almelo, Netherlands) at $45 \mathrm{kV}$ and $40 \mathrm{~mA}$ using a $\mathrm{Cu} \mathrm{K}_{\alpha}$ radiation source with a scanning rate of $2^{\circ} / \mathrm{min}$ and a step of $0.02^{\circ}$. TEM measurements were performed on a JEOL JEM-200CX instrument (Tokyo, Japan) operating at $160 \mathrm{kV}$. We randomly selected 300 particles of the catalyst in the TEM images to determine the mean particle size. Temperature programmed reduction under $\mathrm{H}_{2}$ (TPR) was carried out with a BELCAT instrument (BELL Japan Inc., Osaka, Japan). The calcined sample $\left(0.1 \mathrm{~g}\right.$ of $\mathrm{CuO}-\mathrm{PdO} / \gamma-\mathrm{Al}_{2} \mathrm{O}_{3}$ or $\left.\mathrm{CuO}-\mathrm{PdO} /(\mathrm{M}) \gamma-\mathrm{Al}_{2} \mathrm{O}_{3}\right)$ was heated from $303 \mathrm{~K}$ to $1073 \mathrm{~K}$ at a rate of $10 \mathrm{~K} / \mathrm{min}$ in a flow of $5 \%(\mathrm{~V} / \mathrm{V}) \mathrm{H}_{2} / \mathrm{Ar}(25 \mathrm{~mL} / \mathrm{min})$, and the hydrogen consumption was obtained by a thermal conductivity detector. Temperature-programmed desorption (TPD) of $\mathrm{CO}_{2}$ was conducted on a BELCAT (Osaka, Japan). For example, $0.075 \mathrm{~g}$ of catalyst was heated to $533 \mathrm{~K}$ in a flow of $\mathrm{He}$ ( $30 \mathrm{~mL} / \mathrm{min}$ ) and maintained for $40 \mathrm{~min}$. Then the catalyst was cooled to $303 \mathrm{~K}$ under He flow, and followed by exposing it to a flow of $100 \% \mathrm{CO}_{2}$ for $30 \mathrm{~min}$. Subsequently, the catalyst was purged in $\mathrm{He}$ at $303 \mathrm{~K}$ for $60 \mathrm{~min}$. Finally, the catalyst was heated to $923 \mathrm{~K}$ at a rate of $10 \mathrm{~K} / \mathrm{min}$ in a flow of $\mathrm{He}$, and $\mathrm{CO}_{2}(\mathrm{~m} / \mathrm{e}=44)$, the outlet gas was detected by the mass spectrometer (BELMASS, Osaka, Japan). The Py-FTIR spectra was obtained on a Nicolet 6700 spectrometer (Madison, WI, USA). The sample was heated to $533 \mathrm{~K}$ and kept at this temperature for $1 \mathrm{~h}$ in a vacuum $\left(1 \times 10^{-2} \mathrm{MPa}\right)$, and then cooled down to $303 \mathrm{~K}$, followed by exposure to the vapor of pyridine. The Py-IR spectra was recorded at $303 \mathrm{~K}, 373 \mathrm{~K}$ and $473 \mathrm{~K}$ respectively, in a vacuum for $30 \mathrm{~min}$.

\subsection{Catalytic Tests}

In the experiment, the mixture, composed of $8 \mathrm{~g}$ of the nitroaromatic compound, $0.8 \mathrm{~g}$ of catalyst, $120 \mathrm{~mL}$ of alcohol and $80 \mathrm{~mL}$ of deionized water, was placed in a $500 \mathrm{~mL}$ stainless steel autoclave. The reactor was sealed and purged by high purity $\mathrm{N}_{2}$ five times. Then the pressure in the reactor was raised to 3.5 MPa using $\mathrm{N}_{2}$ after the reactor was heated to the desired temperature, at a stirring rate of $1000 \mathrm{rpm}$. The temperature, pressure and stirring rate were kept constant during the reaction. After the specified reaction time, the reactor was cooled down to room temperature and the pressure in the reaction system was released. The catalyst was filtered from the mixture and the liquid product was qualitatively analyzed using gas chromatography-mass spectrometry (GC-MS, Agilent 5973N, Palo Alto, CA, USA) and quantitatively analyzed by GC (Agilent 7890A, Shanghai, China) equipped with a flame ionization detector (FID) and a DB-1 capillary column $(30 \mathrm{~m} \times 0.32 \mathrm{~mm} \times 3 \mu \mathrm{m})$ using the area-normalization method.

\section{Conclusions}

We efficiently synthesized benzimidazole from low-cost alcohol and o-nitroaniline over a $\mathrm{Cu}-\mathrm{Pd} /(\mathrm{Mg}) \gamma-\mathrm{Al}_{2} \mathrm{O}_{3}$ heterogeneous catalyst. The $\mathrm{Cu}-\mathrm{Pd}$ bimetallic catalyst had better catalytic activity than that of monometallic $\mathrm{Cu}$ or Pd catalyst in the reaction system. It was mainly attributed to the formation of the $\mathrm{CuPd}$ alloy and the synergistic effect between $\mathrm{Pd}$ and $\mathrm{Cu}$. Moreover, the catalytic activity of the $\mathrm{Cu}-\mathrm{Pd} /(\mathrm{Mg}) \gamma-\mathrm{Al}_{2} \mathrm{O}_{3}$ catalyst with the addition of $\mathrm{Mg}$ was superior to $\mathrm{Cu}-\mathrm{Pd} / \gamma-\mathrm{Al}_{2} \mathrm{O}_{3}$, because of the addition of $\mathrm{Mg}$. The formation of the CuPd alloy was promoted and the surface acid 
sites of $\mathrm{Cu}-\mathrm{Pd} / \gamma-\mathrm{Al}_{2} \mathrm{O}_{3}$ catalyst were neutralized, which improved the basicity of the support, as well as enhanced the rate of ethanol dehydrogenation, and finally accelerated the whole reaction system.

Author Contributions: Conceptualization, X.L.; methodology, F.F. and Q.Z; investigation and validation, Y.D. and Z.C.; catalysts characterization, F.F. and C.L.; mechanism analysis, X.X. and L.M.; writing-original draft preparation, F.F.

Funding: Financial support by the National Natural Science Foundation of China $(21406199,21776258$ and 21476208) and the Program for Science and Technology Department of Zhejiang Province (LGG18B060004 and LY17B060008) are gratefully acknowledged.

Conflicts of Interest: The authors declare no conflict of interest.

\section{References}

1. Sharma, S.; Gangal, S.; Rauf, A. Convinient one-pot synthesis of novel 2-substituted benzimidazoles, tetrahydrobenzimidazoles and imidazoles and evaluation of their in vitro antibacterial and antifungal activities. Eur. J. Med. Chem. 2009, 44, 1751-1757. [CrossRef] [PubMed]

2. Shingalapur, R.V.; Hosamani, K.M.; Keri, R.S. Synthesis and evaluation of in vitro anti-microbial and anti-tubercular activity of 2-styryl benzimidazoles. Eur. J. Med. Chem. 2009, 44, 4244-4248. [CrossRef] [PubMed]

3. Ansari, K.F.; Lal, C. Synthesis, physicochemical properties and antimicrobial activity of some new benzimidazole derivatives. Eur. J. Med. Chem. 2009, 44, 4028-4033. [CrossRef] [PubMed]

4. Mungra, D.C.; Patel, M.P.; Patel, R.G. Microwave-assisted synthesis of some new tetrazolo[1,5-a]quinoline-based benzimidazoles catalyzed by $\mathrm{p}-\mathrm{TsOH}$ and investigation of their antimicrobial activity. Med. Chem. Res. 2011, 20, 782-789. [CrossRef]

5. Jain, R.; Agarwal, D.D.; Sahu, P.K.; Selvam, D.T.; Sharma, Y.; Gupta, R.; Prakash, A. Mild and highly efficient copper(II) sulfate catalyzed one pot synthesis of 2-aryl benzimidazole using atmospheric air as an oxidant and its antibacterial study. Med. Chem. Res. 2013, 22, 1788-1794. [CrossRef]

6. Chen, G.Z.; Liu, Z.G.; Zhang, Y.L.; Shan, X.O.; Jiang, L.L.; Zhao, Y.J.; He, W.F.; Feng, Z.G.; Yang, S.L.; Liang, G. Synthesis and anti-inflammatory evaluation of novel benzimidazole and imidazopyridine derivatives. ACS Med. Chem. Lett. 2013, 4, 69-74. [CrossRef] [PubMed]

7. Wang, R.; Lu, X.X.; Yu, X.Q.; Shi, L.; Sun, Y. Acid-catalyzed solvent-free synthesis of 2-arylbenzimidazoles under microwave irradiation. J. Mol. Catal. A Chem. 2013, 22, 1788-1794. [CrossRef]

8. Lu, J.; Ge, H.G.; Bai, Y.J. Solvent-free synthesis of 2-substituted benzimidazoles under microwave-irradiation using PPA as a catalyst. Chin. J. Org. Chem. 2002, 22, 782-784. [CrossRef]

9. Navarrete-Vázquez, G.; Moreno-Diaz, H.; Aguirre-Crespo, F.; León-Rivera, I.; Villalobos-Molina, R.; Muñoz-Muñiz, O.; Estrada-Soto, S. Design, microwave-assisted synthesis, and spasmolytic activity of 2-(alkyloxyaryl)-1H-benzimidazole derivatives as constrained stilbene bioisosteres. Bioorg. Med. Chem. Lett. 2006, 16, 4169-4173. [CrossRef]

10. Sun, P.P.; $\mathrm{Hu}, \mathrm{Z} . X$. The convenient synthesis of benzimidazole derivatives catalyzed by $\mathrm{I}_{2}$ in aqueous media. Heterocycl. Chem. 2006, 43, 773-775. [CrossRef]

11. Lin, S.N.; Yang, L.H. A simple and efficient procedure for the synthesis of benzimidazoles using air as the oxidant. Tetrahedron Lett. 2005, 46, 4315-4319. [CrossRef]

12. Duan, L.P.; Li, Q.; Wu, N.B.; Xu, D.F.; Zhang, H.B. Synthesis of 2,5-disubstitued benzimidazole using $\mathrm{SnCl}_{2}$-catalyzed reduction system at room temperature. Chin. Chem. Lett. 2014, 25, 155-158. [CrossRef]

13. Trivedi, R.; De, S.K.; Gibbs, R.A. A convenient one-pot synthesis of 2-substituted benzimidazoles. J. Mol. Catal. A Chem. 2006, 245, 8-11. [CrossRef]

14. Shen, M.G.; Cai, C. Ytterbium perfluorooctanesulfonates catalyzed synthesis of benzimidazole derivatives in fluorous solvents. J. Fluor. Chem. 2007, 128, 232-235. [CrossRef]

15. Nagawade, R.R.; Shinde, D.B. $\mathrm{BF}_{3} \cdot \mathrm{OEt}_{2}$ promoted solvent-free synthesis of benzimidazole derivatives. Chin. Chem. Lett. 2006, 17, 453-456.

16. Li, X.T.; Hu, R.H.; Tong, Y.; Pan, Q.; Miao, D.Z.; Han, S.Q. An efficient route for the synthesis of benzimidazoles via a hydrogentransfer strategy between o-nitroanilines and alcohols. Tetrahedron Lett. 2016, 57, 4645-4649. [CrossRef] 
17. Fazaeli, R.; Aliyan, H. A Heterogeneous catalyst for efficient and green synthesis of 2-arylbenzothiazoles and 2-arylbenzimidazoles. Appl. Catal. A 2009, 353, 74-79. [CrossRef]

18. Gadekar, L.S.; Arbad, B.R.; Lande, M.K. Eco-friendly synthesis of benzimidazole derivatives using solid acid scolecite catalyst. Chin. Chem. Lett. 2010, 21, 1053-1056. [CrossRef]

19. Shingalapur, R.V.; Hosamani, K.M. An Efficient and eco-friendly tungstate promoted zirconia $\left(\mathrm{WO}_{\mathrm{x}} / \mathrm{ZrO}_{2}\right)$ solid acid catalyst for the synthesis of 2-aryl benzimidazoles. Catal. Lett. 2010, 137, 63-68. [CrossRef]

20. Rathod, S.B.; Lande, M.K.; Arbad, B.R. Synthesis, characterization and catalytic application of $\mathrm{MoO}_{3} / \mathrm{CeO}_{2}-\mathrm{ZrO}_{2}$ solid heterogeneous catalyst for the synthesis of benzimidazole derivatives. Bull. Korean Chem. Soc. 2010, 31, 2835-2840. [CrossRef]

21. Tateyama, K.; Wada, K.; Miura, H.; Hosokawa, S.; Abe, R.; Inoue, M. Dehydrogenative synthesis of benzimidazoles under mild conditions with supported iridium catalysts. Catal. Sci. Technol. 2016, 6, 1677-1684. [CrossRef]

22. Ruiz, V.R.; Corma, A.; Sabater, M.J. New route for the synthesis of benzimidazoles by a one-pot multistep process with mono and bifunctional solid catalysts. Tetrahedron 2010, 66, 730-735. [CrossRef]

23. Chaudhari, C.; Siddiki, S.; Shimizu, K. Acceptorless dehydrogenative synthesis of benzothiazoles and benzimidazoles from alcohols or aldehydes by heterogeneous Pt catalysts under neutral conditions. Tetrahedron Lett. 2015, 56, 4885-4888. [CrossRef]

24. Sun, Z.H.; Bottari, B.; Barta, K. Supercritical methanol as solvent and carbon source in the catalytic conversion of 1,2-diaminobenzenes and 2-nitroanilines to benzimidazoles. Green Chem. 2015, 17, 5172-5181. [CrossRef]

25. Selvam, K.; Swaminathan, M. An easy one-step photocatalytic synthesis of 1-aryl-2-alkylbenzimidazoles by platinum loaded $\mathrm{TiO}_{2}$ nanoparticles under UV and solar light. Tetrahedron Lett. 2011, 52, 3386-3392. [CrossRef]

26. Feng, F.; Ye, J.; Cheng, Z.; Xu, X.X.; Zhang, Q.F.; Ma, L.; Lu, C.S.; Li, X.N. Cu-Pd $/ \gamma-\mathrm{Al}_{2} \mathrm{O}_{3}$ catalyzed the coupling of multistep reactions: Direct synthesis of benzimidazole derivatives. RSC Adv. 2016, 6, 72750-72755. [CrossRef]

27. Fang, W.H.; Zhang, Q.H.; Chen, J.; Deng, W.P.; Wang, Y. Gold nanoparticles on hydrotalcites as efficient catalysts for oxidant-free dehydrogenation of alcohols. Chem. Commun. 2010, 46, 1547-1549. [CrossRef]

28. Shimizu, K.; Kon, K.; Shimura, K.; Hakim, S.S. Acceptor-free dehydrogenation of secondary alcohols by heterogeneous cooperative catalysis between $\mathrm{Ni}$ nanoparticles and acid-base sites of alumina supports. J. Catal. 2013, 300, 242-250. [CrossRef]

29. Scalbert, J.; Thibault-Starzyk, F.; Jacquot, R.; Morvan, D.; Meunier, F. Ethanol condensation to butanol at high temperatures over a basic heterogeneous catalyst: How relevant is acetaldehyde self-aldolization? J. Catal. 2014, 311, 28-32. [CrossRef]

30. Sá, J.; Gross, S.; Vinek, H. Effect of the reducing step on the properties of Pd-Cu bimetallic catalysts used for denitration. Appl. Catal. A 2005, 294, 226-234. [CrossRef]

31. Mierczynskia, P.; Vasilev, K.; Mierczynska, A.; Maniukiewicz, W.; Maniecki, T.P. Highly selective $\mathrm{Pd}-\mathrm{Cu} / \mathrm{ZnAl}_{2} \mathrm{O}_{4}$ catalyst for hydrogen production. Appl. Catal. A 2014, 479, 26-34. [CrossRef]

32. Das, N.N.; Das, R. Synthesis, characterization and activation of quaternary layered double hydroxides for the one-pot synthesis of methyl isobutyl ketone. React. Kinet. Mech. Catal. 2010, 99, 397-408. [CrossRef]

33. Marínez-Ortiz, M.J.; Tichit, D.; Gonzalez, P.; Coq, B. The "one-pot" synthesis of 4-methyl-2-pentanone (methyl isobutyl ketone) from acetone over PdCu catalysts prepared from layered double hydroxides. J. Mol. Catal. A Chem. 2003, 201, 199-210. [CrossRef]

34. Batista, J.; Pintar, A.; Mandrino, D.; Jenko, M.; Martin, V. XPS and TPR examinations of $\gamma$-alumina-supported Pd-Cu catalysts. Appl. Catal. A 2001, 206, 113-124. [CrossRef]

35. Sá, J.; Vinek, H. Catalytic hydrogenation of nitrates in water over a bimetallic catalyst. Appl. Catal. B 2005, 57, 247-256. [CrossRef]

36. Guy, K.A.; Xu, H.P.; Yang, J.C.; Werth, C.J.; Shapley, J.R. Catalytic nitrate and nitrite reduction with $\mathrm{Pd}-\mathrm{Cu} / \mathrm{PVP}$ colloids in water: composition, structure, and reactivity correlations. J. Phys. Chem. C 2009, 113, 8177-8185. [CrossRef]

37. Cosimo, J.I.D.; Díez, V.K.; Xu, M.; Iglesia, E.; Apesteguía, C.R. Structure and surface and catalytic properties of Mg-Al basic oxides. J. Catal. 1998, 178, 499-510. [CrossRef]

38. Díez, V.K.; Apesteguía, C.R.; Cosimo, J.I.D. Effect of the chemical composition on the catalytic performance of $\mathrm{Mg}_{y} \mathrm{AlO}_{x}$ catalysts for alcohol elimination reactions. J. Catal. 2003, 215, 220-233. [CrossRef] 
39. Busca, G. Spectroscopic characterization of the acid properties of metal oxide catalysts. Catal. Today 1998, 41, 191-206. [CrossRef]

40. Devassy, B.M.; Lefebvre, F.; Halligudi, S.B. Zirconia-supported 12-tungstophosphoric acid as a solid catalyst for the synthesis of linear alkyl benzenes. J. Catal. 2005, 231, 1-10. [CrossRef]

(c) 2018 by the authors. Licensee MDPI, Basel, Switzerland. This article is an open access article distributed under the terms and conditions of the Creative Commons Attribution (CC BY) license (http:/ / creativecommons.org/licenses/by/4.0/). 